\title{
„ZELENA ŠTAJERSKA I CVJETNI GRAZ“ U ZAGREBU. PRILOG POZNAVANJU HRVATSKO-ŠTAJERSKIH VEZA 1960-IH GODINA
}

U članku autor analizira razvoj $i$ dinamiku turističkih odnosa između austrijske pokrajine Štajerske $i$ Socijalisticke Republike Hrvatske. Naglasak pritom stavlja na ponovno intenziviranje hrvatsko-stajerskih odnosa u vrijeme reformskih strujanja u hrvatskom partijskom vodstvu koncem 1960-ih i ranih 1970-ih. Ističe važnost turizma, kao ključnog mosta suradnje između Štajerske i Hrvatske općenito, te gradova Graza i Zagreba posebno.

Ključne riječi: Hrvatska, Štajerska, gospodarstvo, turizam, kultura, Graz, Zagreb

I Vi biste trebali jednom poduzeti jedno putovanje u naš grad u srce „Zelene Štajerske". Vi ćete sigurno radosno konstatirati: $U$ Graz vrijedi putovati!

zamjenik gradonačelnika Graza Alexander Götz ${ }^{1}$

\section{Počeci hrvatsko-štajerske suradnje u drugoj polovini 1960-ih}

$\bigcup$ sklopu općih bilateralnih odnosa Jugoslavije i Austrije posebno značajno mjesto zauzimala je suradnja na regionalnom planu između SR Slovenije i SR Hrvatske te austrijskih pokrajina Koruške, Štajerske i Gradišća. Zahvaljujući dugogodišnjim intenzivnim vezama i odnosima na ovome području te prirodnoj upućenosti na suradnju, u drugoj polovini 1960-ih ostvareni su zapaženi rezultati koji su se manifestirali u vrlo živoj ekonomskoj suradnji, intenziviranju turističke i malogranične razmjene, bogatoj i raznovrsnoj kulturnoj i sportskoj aktivnosti te drugim zajedničkim nastupima. Osobito su bili intenzivirani kontakti između gradova i pograničnih općina dviju zemalja. Pored pozitivnih aspekata i obostrane koristi na općem bilateralnom planu, regionalna suradnja predstavljala je značajan faktor i u odnosu na slovensku manjinu u Koruškoj ${ }^{2}$ i hrvatsku u Gradišću. ${ }^{3}$

1 Götz je 1958. izabran za vijećnika u gradačkom gradskom Vijeću i u Senatu. Za zamjenika gradonačelnika izabran je 1964., a konačno, 1973. godine, i za gradonačelnika grada Graza. https://derstandard. at/2000072547017/Grazer-Alt-Buergermeister-Alexander-Goetz-gestorben (posjet 19. 6. 2019)

2 O odnosima između Slovenije i Austrije v. zbornik radova Slovensko-avstrijski odnosi v 20. stoletju (ur. Dušan Nećak i dr.), Ljubljana 2004.

3 O vezama između Hrvatske i Gradišća više u: Božena Vranješ-Šoljan, Gradišćanski Hrvati između tradicije i suvremenosti, Zagreb 2005; Arnold Suppan, „Gradišćanski Hrvati. Integracija i asimilacija u 20. stoljeću: U povodu godišnjice doseljenja“, Radovi Instituta za hrvatsku povijest, 16, 1983, 5-42; Mirko Valentić, Gradišćanski Hrvati od XVI stoljeća do danas, Zagreb 1970. 
U razvijanju daljnjih odnosa između Jugoslavije i Austrije značajnu ulogu odigrao je i niz drugih elemenata, kao što su bili: suradnja komora na svim razinama, suradnja niza privrednih organizacija, znanstvenih i drugih institucija, zatim česti i brojni posjeti stanovnika u obama pravcima, prisutnost jugoslavenskih radnika u Austriji i drugo.

Ukupni jugoslavensko-austrijski odnosi razvijali su se 1960-ih i 1970-ih godina iznimno dobro te se s obiju strana isticalo kako mogu poslužiti kao primjer suradnje dviju zemalja u regiji. ${ }^{4}$ Upravo u duhu tih dobrosusjedskih i prijateljskih odnosa došlo je i do uzvratnog posjeta ${ }^{5}$ predsjednika Savezne Republike Austrije Franza Jonasa jugoslavenskom predsjedniku Titu i SFRJ 1968. godine ${ }^{6}$, prilikom kojeg je austrijski predsjednik posjetio i SR Hrvatsku i njezin glavni grad Zagreb te Dubrovnik.? U takvom općem jugoslavensko-austrijskom kontekstu uspješno se razvijala i suradnja između vlada Zemaljske pokrajine Štajerske i Socijalističke Republike Hrvatske, a isto tako i suradnja njihovih gospodarskih, kulturnih i društvenih organizacija i institucija. Predsjednica Izvršnog vijeća Sabora SR Hrvatske dr. Savka Dabčević-Kučar ${ }^{8}$ doputovala je 4. prosinca 1967. godine u Graz, u službeni posjet Pokrajinskoj vladi Štajerske, na poziv njezina predsjednika Josefa Krainera. ${ }^{9}$ Dočeku u Grazu prisustvovali su predsjednik Pokrajinske vlade Štajerske Krainer s članovima Vlade, jugoslavenski ambasador u Austriji Lazar Mojsov i generalni konzul SFRJ u Grazu Zdenko Dostal. ${ }^{10}$ Tijekom trodnevnog posjeta štajerskoj metropoli razmatrala su se pitanja konkretnih oblika suradnje u privredi i kulturi između zainteresiranih organizacija i institucija SR Hrvatske i Štajerske. Tijekom razgovora pokazale su se i povoljne mogućnosti daljnjeg proširenja i jačanja suradnje Hrvatske i Štajerske u spomenutim oblastima. Isticala se i mogućnost uspostavljanja dugoročne suradnje, uz zaključenje odgovarajućih aranžmana. Predsjednik Pokrajinske vlade Štajerske Krainer prihvatio je poziv Savke Dabčević-Kučar da sa svojim suradnicima uskoro posjeti SR Hrvatsku te je u čast gostiju iz Hrvatske priredio svečani prijam na kojemu su bili predstavnici političkog, kulturnog i javnog života Štajerske. ${ }^{11}$

4 O jugoslavensko-austrijkkim odnosima nakon Drugoga svjetskog rata v. više u: Petar Dragišić, Odnosi Jugoslavije i Austrije 1945-1955, Beograd 2013.

5 Josip Broz Tito boravio je u službenom posjetu Republici Austriji u veljači 1967. godine.

6 "Susret jugoslovenskih i austrijskih novinara s predsednicima Titom i Jonasom“, Politika (Beograd), 6. 10. 1968, 3.

7 Večernji list (Zagreb), 3. 10. 1968, 1.

8 Na toj je dužnosti bila od 1967. do 1968. godine, a od 1968. godine predsjednica je CK SKH. Nakon XXI. sjednice Predsjedništva SKJ u Karađorđevu u prosincu 1971., bila je prisiljena podnijeti ostavku na funkciju predsjednice CK SKH, potom je isključena iz SKH, uklonjena s fakulteta i iz javnog života. Više o njezinu životu i djelovanju u navedenim godinama v. u: Savka Dabčević-Kučar, '71. Hrvatski snovi i stvarnost, I-II, Zagreb 1997.

9 Josef Krainer obnašao je navedenu dužnost od 1948. do 1971. godine. Od 1965. do 1971. predsjednik je štajerske Narodne stranke, a njegov sin - Josef Krainer mlađi - bio je zemaljski poglavar Stajerske od 1980. do 1996. godine. O Josefu Kraineru starijem više u: Kurt Wimmer, "Josef Krainer sen. Vom Landarbeiter zum Landesvater", u: Die Landeshauptleute der Steiermark (Hrsg. Alfred Ableitinger - Herwig Hösele - Wolfgang Mantl), Graz 2000, 102-123.

10 „Dr. Savka Dabčević-Kučar u Grazu“, Vjesnik (Zagreb), 5. 12. 1967, 1.

11 „Dr. Savka Dabčević-Kučar otputovala iz Graza“, Vjesnik (Zagreb), 7. 12. 1967, 1. 


\section{Zagreb kao austrijska turistička destinacija}

Austrija je za SFRJ, nakon Savezne Republike Njemačke, bila najvažnija zemlja iz koje su dolazili strani turisti. I iz austrijske perspektive Jugoslavija je kao cilj putovanja zauzimala vrlo visoko mjesto, odmah iza Italije. ${ }^{12}$ Priljev turista, kako austrijskih tako i svih ostalih inozemnih gostiju, bio je usko povezan s jugoslavenskom vanjskom politikom i njezinim okretanjem prema Zapadu nakon 1948. godine. Stvarni se polet u domaćem turizmu osjetio između 1952. i 1953., a pritom su novi sporazumi s inozemnim putničkim agencijama smještenim u SAD-u, Francuskoj, Engleskoj i Austriji također igrali svoju ulogu u unapređivanju rasta inozemnog turizma. ${ }^{13} \mathrm{U}$ skladu s procesima decentralizacije turističke propagande, „početkom 1950-ih republički turistički savezi Hrvatske i Slovenije već su počeli objavljivati vodiče i brošure kojima su promovirale svoje republike na stranim jezicima. ${ }^{114}$ Upravo u ovome razdoblju Zagreb se nastojao afirmirati kao međunarodno važna sredina. Kako bi uspostavio što bliže i intenzivnije veze s gradovima u regiji i šire, gradske vlasti pokreću akciju „Gradovi prijatelji“, kojom je Zagreb, „počevši od 1959. uspostavio takve odnose sa cijelim nizom gradova u Europi i cijelom svijetu. ${ }^{\prime 15}$

U razdoblju od 1963. do 1967. godine turistički promet u gradu Zagrebu pokazivao je stalne tendencije rasta, osim u 1965. godini, kada je prvi put došlo do ozbiljnijeg pada noćenja domaćih turista, što je imalo utjecaja na pad cjelokupnog turističkog prometa u Zagrebu. ${ }^{16}$ Međutim, unatoč tome privremenom zastoju, noćenja inozemnih turista pokazuju tijekom cijelog vremena stalnu i veoma visoku stopu rasta. Godine 1966. u Zagrebu je prvi put ostvaren veći broj inozemnih nego domaćih noćenja, što je, međutim, više bila posljedica izrazitog pada domaćih nego uočljivog porasta inozemnih noćenja. ${ }^{17}$

Glede nacionalne strukture noćenja inozemnih turista u Zagrebu te sudjelovanja Zagreba u ostvarenim noćenjima pojedinih nacionalnosti u Jugoslaviji, osobito je znakovit udio austrijskih turista. Prema raspoloživim podacima za 1963. i 1964. godinu, u Zagrebu je tih godina zabilježen broj noćenja od 23.609, odnosno 24.237 gostiju iz Austrije. Udio Zagreba u ukupnim inozemnim noćenjima Jugoslavije kretao se inače u tim dvjema godinama na razini od 2,2\%. Karakteristično je, naime, da je Zagreb apsorbirao najmanji postotak inozemnih noćenja upravo od onih zemalja koje su po nacionalnoj strukturi inozemnih noćenja u Jugoslaviji imale najviši udio (SR Njemačka i Austrija po 0,9\% u 1966. g. i 0,8\% u 1967. g.), iako bi s obzirom na tranzitno turistički položaj Zagreba u odnosu na ovo tržište te mogućnosti vikend turizma udio Zagreba u apsorpciji noćenja

12 Waltraut Urban, „Austrijsko-jugoslavenski privredni odnosi“, Politička misao, XXIII/3, 1986, 69.

13 Igor Tchoukarine, "Jugoslavenski put do međunarodnog turizma. Otvaranje, decentralizacija i propaganda u prvoj polovici 1950-ih", u: Sunčana strana Jugoslavije. Povijest turizma u socijalizmu (ur. Hannes Grandits - Karin Taylor), Zagreb 2013, 127.

14 Isto, 147.

15 Povijest grada Zagreba, II.: 20. i 21. stoljeće, Zagreb 2013, 253.

16 Vjerojatan razlog toj negativnoj pojavi predstavljala je velika poplava koja je zahvatila grad Zagreb 1964. godine i nanijela veliku materijalnu štetu te zaustavila na određeno vrijeme razvojne tendencije prisutne od sredine pedesetih godina i „prekoračenja“ grada preko Save u vrijeme gradonačelnika Većeslava Holjevca.

17 Državni arhiv u Zagrebu (dalje: DAZG), Skupština grada Zagreba (dalje: SGZ), HR-DAZG 948, Zapisnici zajedničke sjednice 1968. (9-12 sjednica), III, Turizam Zagreba - karakteristike, aktuelnosti i perspektive, Izradio: Turistički savez Zagreba, Zagreb, travnja 1968., 3/2577. 
ovih zemalja ostvarenih u Jugoslaviji trebao biti iznad ukupnog udjela Zagreba u inozemnim noćenjima Jugoslavije. ${ }^{18}$

Za inozemni turistički promet u gradu Zagrebu tri turistička tržišta - Austrija, Italija i Mađarska - imala su specifičnu funkciju, koja je proizlazila iz njihova geografskog položaja i relativno male udaljenosti od Zagreba, ali i povijesno-tradicionalnih veza koje su upućivale ove zemlje i gradove jedne na druge. Naime, od svih inozemnih tržišta samo se od spomenutih triju mogao očekivati masovniji promet u Zagrebu tijekom cijele godine. $U$ 1967. godini turistički promet iz Austrije kretao se po mjesecima ovako:

Tablica 1. Turistički promet s Austrijom po mjesecima 1966./1967. ${ }^{19}$

\begin{tabular}{|l|l|}
\hline Mjesec & Indeks noćenja 1966./1967. \\
\hline I. & 161,6 \\
\hline II. & 163,4 \\
\hline III. & 60,0 \\
\hline IV. & 123,8 \\
\hline V. & 95,9 \\
\hline VI. & 106,3 \\
\hline VII. & 115,4 \\
\hline VIII. & 71,7 \\
\hline IX. & 91,6 \\
\hline X. & 132,3 \\
\hline XI. & 108,1 \\
\hline XII. & 142,8 \\
\hline Ukupno god. & 102,7 \\
\hline
\end{tabular}

Uočljivo je da se turistički promet iz Austrije u glavnom hrvatskom gradu odvijao vrlo neujednačenim tijekom. Tako se u siječnju i veljači, travnju, lipnju, srpnju, listopadu, rujnu i prosincu ostvaruje vrlo izražena stopa rasta (u veljači - indeks 163,4), dok je u ožujku, svibnju, kolovozu i rujnu izraziti pad (u ožujku - indeks 60,0). ${ }^{20}$

U Turističkom savezu Zagreba (TSZ) razmatrali su pitanje ostvarenja što većeg rasta turističkog prometa s Austrijom te je zaključeno da se mora povećati propaganda na spomenutom tržištu, a osobito na području Štajerske, Koruške i Burgenlanda/Gradišća te time „smanjiti za Zagreb negativan utjecaj, koji rezultira iz u zadnje vrijeme intenzivne propagande iz Mađarske i konstantno solidne propagande iz Slovenije. “21 Također se težilo prema razvijanju vikend i izletničkog turizma iz Austrije na općem planu plasmana turističke

18 Isto, 15-16/2549-50. U strukturi inozemnih noćenja u Zagrebu u 1967. godini najviši udio imali su: Italija 22,0\%, SR Njemačka 10,4\%, Francuska 8,0\%, Čehoslovačka 7,7\%, Austrija 7,0\%, SAD 5,2\% i Velika Britanija 4,95\%.

19 Izvor: DAZG, SGZ, HR-DAZG 948, Zapisnici zajedničke sjednice 1968. (9-12 sjednica), III, Turizam Zagreba - karakteristike, aktuelnosti i perspektive, Izradio: Turistički savez Zagreba, Zagreb, travnja 1968., $25 / 2599$.

20 Isto, 26/2600.

21 Isto. 
ponude u Austriji, a osobito organiziranjem atraktivnih manifestacija, kulturno-povijesnih sadržaja, zdravstveno-lječilišnih usluga, zanatskih usluga, predstavljanja trgovačke robe široke potrošnje, kupališnih usluga u toplicama i lovno-turističke ponude. Zanimljivo je da se sugeriralo da se propagandna aktivnost i općenito obrada austrijskog tržišta usmjeri s ciljem pretvaranja Zagreba u glavno turističko-tranzitno čvorište u pravcima kretanja austrijskih turista prema Jadranskom, Egejskom i Crnom moru. ${ }^{22}$

Ovdje treba napomenuti kako u obradi inozemnog turističkog prometa nisu dani ni apsolutni ni relativni pokazatelji inozemnog tranzitnog, vikend i izletničkog prometa u Zagrebu jer TSZ nije raspolagao pouzdanim podacima o ovim oblicima turizma, već samo procjenama. Ukupno gledavši, inozemni je turistički promet na širem zagrebačkom području u 1967. godini registrirao porast noćenja za oko $40 \%$ u odnosu na 1966. godinu, a u narednim se godinama mogao samo predviđati značajniji porast. ${ }^{23}$ Međutim, problem je bio u tome što je inozemni izletnički promet na ovom području bio još uvijek neznatan te je pokazivao vrlo niske stope rasta od oko 5\%, a upravo je ovom obliku inozemnog turizma trebalo, smatrali su turistički stručnjaci, posvetiti posebnu pozornost. Razvoj ovog oblika turizma na vanjskom području mogao je izravno utjecati na pozitivan razvoj boravišnog, a posebno više puta spominjanog vikend i izletničkog turizma u Zagrebu iz Austrije, Italije i Mađarske. Konstatacije o vrlo povoljnoj perspektivi rasta takve vrste inozemnog turizma prvenstveno su se odnosile na Hrvatsko zagorje, zbog predviđenog skorog dovršenja Zagorske magistrale te relativno brojčano dovoljnog i kvalitetnog unapređenja kapaciteta i plasmana ponude.

Veliku zapreku razvoju turističke ponude Zagreba predstavljao je komunikacijski faktor ponude, odnosno cestovna infrastruktura. Označene turističke funkcije Zagreba, osobito one tranzitne, kao ni priželjkivani posjet domaćih, a posebice inozemnih posjetitelja, nisu bili izgledni ako se prethodno ne bi do početka ljetne turističke sezone izgradili sljedeći cestovni potezi:

1. u 1968. godini - Krapina - Rogaška Slatina; Gospić - Karlobag; Otočac - Senj

2. u 1969. godini - rekonstrukcija ceste Varaždin - Zagreb - Karlovac

3. u 1970. godini - Zagorska magistrala, dovršenje na potezu Krapina - Ptuj. ${ }^{24}$

Upravo su djelatnici TSZ-a bili među najglasnijima prilikom upozoravanja nadležnih gradskih i republičkih vlasti da sve dok se ne moderniziraju, odnosno izgade označene cestovne prometnice, tranzitno-turistička uloga Zagreba - iz koje on crpi pretežni dio turističke potražnje - bit će u neprestanom relativnom padu jer se turistički pravci usmje-

22 Isto. U Zaključcima TSZ-a glede dotadašnjeg razvoja i daljnjih perspektiva razvoja zagrebačkog turizma posebice je istaknuto: „Od poboljšanja i učvršćenja geoprometne funkcije Zagreba u glavnim tokovima kretanja turističke klijentele između emitivno turističkih zemalja Evrope, te receptivnih područja na obalama Jadranskog, Crnog, Egejskog i Mramornog mora, moguće je postići: a) izgradnjom Zagorske magistrale, te dovršenjem poteza Gospić-Karlobag i Otočac-Senj, zatim rekonstrukcijom poteza Zagreb-Beograd; b) rekonstrukcijom pristupnica gradu, te suvremenim reguliranjem prometnica i prometa od gradskih periferija i garažnog prostora u poslovnom tkivu grada. "; Isto, 2651.

23 Isto, 29/2603.

24 U tom smislu bilo je vrlo važno da se do 1969. godine u gradu izgradi cesta Vrapče - Podsused jer se pretpostavljalo da bi u protivnom taj prostor mogao predstavljati „usko grlo“ zapadnom prilazu grada sa spomenute Zagorske magistrale. 
ravaju boljim prometnicama, koje ne tangiraju Zagreb. Može se zato reći kako je uslijed dotadašnjeg stanja cestovne povezanosti Zagreba s jadranskim turističkim područjem i Središnjom Europom glavni hrvatski grad bio samo simbolično uključen u programe i itinerare domaćih i inozemnih putničkih agencija i ostalih organizatora putovanja. Štoviše, izgradnja označenih cestovnih prometnica nije bila samo u interesu grada Zagreba, već gotovo cijele Hrvatske, a posebno njezinih najnerazvijenijih dijelova - Like, Korduna, Hrvatskog zagorja - pa je za rješavanje ovog problema bilo nužno, osim zainteresiranih gradskih vlasti, i uključenje republičkih faktora.

U smislu što veće turističke ponude Zagreba krenulo se u drugoj polovini 1960-ih na intenzivno propagiranje zabavnih, kulturnih, umjetničkih i drugih ponuda grada u inozemstvu. Kada je o Štajerskoj riječ, važno je istaknuti kako je 1967. godine TSZ objavio oglas povodom "Zagorske svadbe" u gradačkom dnevnom listu Kleine Zeitung, dok je s ciljem propagiranja predstojeće "Smotre folklora“ iste godine održana konferencija za tisak u Grazu, kao i u Klagenfurtu i Beču te Trstu. ${ }^{25}$ Sredstvima TSZ-a financirano je sudjelovanje ove turističke zajednice na Sajmu u Grazu 1965. i 1967. godine. Štoviše, sredinom srpnja 1967. otvorena je i nova autobusna linija Zagreb - Graz, koju je održavala tvrtka „Croatiatrans". Na TV Zagreb prikazan je u sklopu emisije "Jučer, danas, sutra“ i kraći prilog u kojem su prikazani prvi putnici koji ulaze u autobus, vožnja kroz Graz, konferencija za tisak u povodu otvorenja nove autobusne linije, panorama i glavne znamenitosti Graza. ${ }^{26}$

Sva nastojanja usmjerena su tada na propagiranje zagrebačkih turističkih mogućnosti u inozemstvu, posebno u susjednim zemljama, Italiji i Austriji, odakle se i očekivao najveći priljev. Glavni su „aduti“ u svijetu svakako bili već renomirana "Smotra folklora“, potom tradicionalni Zagrebački velesajam, kojem su poseban pečat trebale dati brojne priredbe zabavnog, kulturnog i folklornog karaktera pod zajedničkim nazivom "Hrvatski rujan“, zatim tada već također tradicionalni ciklus manifestacija poznatih pod imenom „Zagorski tjedan“, koji je također trebao prerasti u „Zagorski rujan“ itd. Također je bilo odlučeno da treba što hitnije održati konferencije za novinare u najbližim gradovima Italije i Austrije (Trst, Udine, Gorica, Klagenfurt, Graz, možda i Beč te Gradišće), pozvati neke inozemne reportere i snimatelje te što efektnije nastupiti na inozemnim sajmovima. ${ }^{27}$

Na temelju inicijative Turističkog saveza Graza, kojoj se potom pridružio i Turistički savez Štajerske, ujesen 1967. godine uspostavljeni su kontakti između ovih organizacija i Turističkog saveza Zagreba.

\section{3. „Štajerski tjedan“ u Zagrebu}

Posljedica razgovora hrvatske i štajerske Vlade o unapređenju bilateralnih odnosa, osobito glede razvoja turističkih veza, rezultirala je daljnjim razgovorima između predstavnikâ turističkih organizacija. Krajem veljače 1968. godine delegacija Graza i Turističkog saveza Štajerske boravila je u službenom posjetu Zagrebu. Tijekom posjeta razgovaralo

25 Isto, 57/2631; 60/2634.

26 Zahvaljujem kolegi Vladimiru Brnardiću s Hrvatske radiotelevizije na ovoj važnoj informaciji i na uvidu u sadržaj spomenute emisije.

27 „Fond u deficitu“, Večernji list (Zagreb), 14. 7. 1967, 9. 
se o suradnji Zagreba i Graza, kao i o predstojećem „Tjednu zelene Štajerske i cvjetnog Graza“, koji se trebao održati u Zagrebu tijekom iste godine. ${ }^{28}$ Da je bila riječ o već unaprijed utvrđenom programu suradnje, potvrđuje i činjenica da je samo dva mjeseca poslije u Zagrebu započeo tzv. „Štajerski tjedan“.

Otvaranjem prigodne izložbe u Umjetničkom paviljonu, pod pokroviteljstvom dr. Savke Dabčević-Kučar, predsjednice Izvršnog vijeća Sabora, i Josefa Krainera, predsjednika Zemaljske vlade Štajerske, počeo je 20. travnja 1968. "Tjedan zelene Štajerske i cvjetnog Graza“ u glavnom hrvatskom gradu. Već samo otvaranje „Štajerskog tjedna“ u Zagrebu izazvalo je val pozitivnih kritika u zagrebačkoj javnosti. Tako se često isticalo da je Zagreb "otvorena srca“ prihvatio „nesvakidašnji posjet drugog po veličini grada u Austriji - Graza - i velike pokrajine Štajerske“. Od subote 20. travnja 1968., otkako je u Umjetničkom paviljonu otvorena izložba o Štajerskoj u prisutnosti predsjednika Zemaljske vlade Štajerske Josefa Krainera, potpredsjednika Izvršnog vijeća Sabora Milana Miškovića, gradonačelnika Graza, dipl. inž. Gustava Scherbauma ${ }^{29}$, predsjednika Skupštine grada Zagreba Josipa Kolara ${ }^{30}$ i ostalih gostiju, zagrebačko je novinstvo sa zanimanjem i simpatijama pratilo manifestacije, čiji je cilj bio upoznati Zagrepčane s karakteristikama i dostignućima susjedne austrijske pokrajine. U povodu manifestacije "Zelena Štajerska i cvjetni Graz", Milan Mišković, potpredsjednik Izvršnog vijeća Sabora, priredio je prijam i svečani ručak za delegaciju štajerske Vlade, čime je hrvatska strana uzvratila posjetom delegacije Izvršnog vijeća Sabora SR Hrvatske Štajerskoj. ${ }^{31}$ Istog dana predsjednik Gradske skupštine Josip Kolar primio je delegaciju grada Graza na čelu s gradonačelnikom, dipl. inž. Gustavom Scherbaumom, kojom se prilikom razgovaralo o nastavku suradnje između dvaju gradova. Josef Krainer, predsjednik štajerske Vlade, priredio je u hotelu „Esplanade-International“ svečani prijam, kojem su, pored brojnih uzvanika, predstavnikâ političkog i privrednog života Zagreba, prisustvovali Milan Mišković, Ivan Krajačić, Ivan Buković, Josip Kolar, Ratko Karlović i druge ličnosti. ${ }^{32}$ I predsjednik Skupštine grada Zagreba Josip Kolar primio je u Vijećnici gradonačelnika Graza Scherbauma i potpredsjednika, dipl. ing. Alexandera Götza, te im je poklonio monografiju o gradu Zagreba. ${ }^{33}$ Svakoga dana, do petka 26. travnja, održavale su se zanimljive kulturne, gospodarske, turističke, sportske i kulinarske manifestacije koje su upoznale Zagrepčane sa životom i znamenitostima ove austrijske pokrajine.

Nakon službenog otvaranja, već iduće večeri nastavio se bogati program gostovanja "Zelene Štajerske i cvjetnog Graza“ u Zagrebu originalnom priredbom održanom u Gradskom podrumu. Naime, priređena je tipična štajerska večer pod nazivom „Graz uz pivo i glazbu“, tijekom koje su se posjetitelji imali prilike upoznati s austrijskom glazbom te počastiti svjetski poznatim pivom kuće "Reininghaus-Puntigam“, tada i danas najvećom u Štajerskoj i drugoj po veličini pivovari u Austriji, čija je godišnja produkcija iznosila milijun hektolitara te se izvozila u mnoge zemlje, među kojima i u Jugoslaviju. ${ }^{34}$ Za vrijeme te

28 Revija Zagreb, 1, travanj 1968, 44.

29 Gustav Scherbaum obnašao je dužnost gradonačelnika Graza čak trinaest godina, od 9. veljače 1960. do 24. travnja 1973. O tim iznimno zanimljivim i važnim godinama objavio je svoja sjećanja pod naslovom: Erinnerungen eines Grazer Bürgermeisters, Graz 1985.

30 Josip Kolar Matek, gradonačelnik Zagreba od 1967. do 1972. godine.

31 „Bogata posjetnica“, Večernji list (Zagreb), 22. 4. 1968, 4.

32 Isto.

33 Revija Zagreb, 1, travanj 1968, 44.

34 "Graz uz pivo i glazbu“, Isto, 13. 
priredbe s degustacijom održana je i modna revija tipično austrijskih modela iz modnih kuća iz Graza. Tijekom večere potpredsjednik zagrebačke Skupštine Ratko Karlović otvorio je 500-litarsku bačvu piva u Gradskom podrumu te je time otvorio večer "Graz uz pivo i glazbu“. ${ }^{35}$ Ova priredba bila je jedna od najoriginalnijih i najveselijih $u$,"Štajerskom tjednu“. Zagrepčanima su Gračani nazdravili pivom i pozvali ih da što prije uzvrate posjet i predstave se Grazu. Ratko Karlović, potpredsjednik Skupštine grada, odzdravio je također pivom, ali i najavio: "na odlično i poznato štajersko pivo Zagreb će Grazu odgovoriti kvalitetnim - vinom! ${ }^{36}$

Tijekom travanjskih manifestacija u Studentskom centru održana je velika folklorna priredba "Štajerska u pjesmi i plesu“, a članovi opere iz Graza izveli su Figarov pir W. A. Mozarta u Domu Jugoslavenske armije. Bila je riječ o opernom ansamblu Udruženih pozornica Graza koje su se ubrajale među tada najveće kazališne ustanove Austrije. Unutar tog kazališta, koje je raspolagalo dvjema velikim suvremenim uređenim kućama, djelovali su Drama, Opera i Balet, a u njegovu su se ansamblu uvijek nalazila i poznata imena kazališnog svijeta. Dovoljno je spomenuti da su u tom kazalištu s velikom tradicijom započeli u prošlom stoljeću svoje karijere Johann Nestroy i Alexander Girardi te čuveni dirigenti Clemens Krauss i Karl Böhm. U opernom ansamblu Graza često su djelovali i hrvatski umjetnici, a u vrijeme zagrebačkoga gostovanja već ga je niz godina i s mnogo uspjeha vodio zagrebački dirigent Berislav Klobučar. ${ }^{37}$ Nekoliko sezona kao operna prvakinja provela je u Grazu i Božena Ruk-Fočić. lako je posljednjih godina operni ansambl glavnoga grada Štajerske gostovao češće u Beču, kao i u inozemstvu, u SFRJ nastupio je već u Ljubljani i Mariboru, dok mu je ovaj nastup u Zagrebu predstavljao prvo gostovanje. U Domu JNA, na privremenoj pozornici zagrebačke Opere, izveli su operni umjetnici iz Graza Figarov pir W. A. Mozarta koji je bio stalno na njihovu repertoaru. Pod ravnanjem Gustava Cernyja naslovnu ulogu pjevao je Artur Korn, grofa Almavivu Hans Helm, koji je istu ulogu pjevao već u Zagrebu (u koncertnoj izvedbi Zagrebačke filharmonije), a ostale uloge Waltraud Schwind (Grofica), Elisabeth Görner (Marcelina), Engelbert Domig (Bastolo), Erich Klaus (Basilio), Helmut Böhm (Curzio), Heinz-Klaus Ecker (Antonio) i Adelheid Mayr (Barbarina). Mozartova komična opera izvedena je u režiji Andréa Diehla, bivšeg intendanta Udruženih pozornica Graza, poznatog tadašnjoj zagrebačkoj publici po svojoj postavi Šišmiša u HNK-u. ${ }^{38}$ Idućeg dana zagrebačka je kritika pohvalila cjelokupnu izvedbu, scenografiju i kostimografiju te posebice istaknula „izvrsne muške protagoniste, Hansa Helma kao grofa Almaviva, Artura Korna u naslovnoj ulozi Figara i bečkog Don Bartola Aloisa Pernerstorfera; od manjih ulogu Heinza-Klausa Eckera kao Antonija. ${ }^{\text {39 }}$

35 Također je održana i revija modela jedne modne kuće iz Graza. Isto, 45.

36 Isto.

37 Berislav Klobučar djelovao je i kao generalni glazbeni direktor Štajerske (njem. Generalmusikdirektor für Steiermark), odnosno šef-dirigent Opere i Simfonijskoga orkestra u Grazu (1960. - 1971.).

38 Večernji list (Zagreb), 20. 4. 1968, 6. Zbog oboljenja člana Engelberta Domiga, Opera UPG-a zatražila je pomoć iz Beča za svoje zagrebačko izvođenje Figarova pira. Tako je, umjesto spomenutog Domiga, ulogu doktora Bartola pjevao komorni pjevač Alois Pernerstorfer, solist Bečke državne opere. Taj je poznati bečki basist već godinama nastupao u izvedbama svoje kuće, kao i na Svečanim izvedbama u Salzburgu. Iz Beča došla je i protagonistica Marceline koju je pjevala mezzosopranistica Eva Görner. U ulozi Suzane nastupila je, umjesto ranije najavljene Elisabeth Lachmann, sopranistica Eta Köhrer., Večernji list (Zagreb), 22. 4. 1968, 5.

39 "Iskreni pljesak“, Isto, 9. 
U sklopu glazbenih večeri posvećenoj Štajerskoj održane su i druge manifestacije. Tako je predavanje pod naslovom „Muzička Štajerska“, s komornom glazbom, održano u Narodnom sveučilištu u Medulićevoj ulici, a predavači su bili dr. Bruno Binder-Krieglstein i dr. Paul Kaufmann. Na Komornoj pozornici Studentskog centra solistički koncert izveo je Werner Tripp, prvi solo flautist Bečke filharmonije, koji se u to vrijeme ubrajao među najpoznatije europske majstore tog instrumemnta. Uz klavirsku pratnju, Gertie Kaan austrijski flautist izveo je djela Mozarta, Schuberta, Beethovena, Martinua i Prokofjeva. U Austrijskoj čitaonici nastupio je, pak, E. L. Uray, jedan od vodećih tadašnjih austrijskih kompozitora, predavanjem "Tonovi i boje“. ${ }^{40}$

Međutim, osim glazbenih manifestacija, odvijala su se i druga događanja vezana uz kulturne i pedagoške sadržaje koje je štajerska strana predstavila hrvatskom domaćinu. Šef Odjela za obrazovanje Radničke komore i direktor Narodnog sveučilišta pri istoj komori, doktor Franz Scheucher, te tajnik najvećeg Narodnog sveučilišta iz Graza Uranije Peter Schall boravili su kao gosti Saveza narodnih i radničkih sveučilišta Hrvatske u Zagrebu 24. i 25. travnja. Tim povodom Savez narodnih i radničkih sveučilišta Hrvatske organizirao je u svojim prostorijama u Vojnovićevoj 42 razgovore s poznatim austrijskim andragozima u vezi s daljnjom suradnjom na području obrazovanja odraslih između Štajerske i Hrvatske. Za vrijeme svojeg boravka u Zagrebu štajerski gosti posjetili su novouređeno Narodno sveučilište Peščenica u Zagrebu, Narodno sveučilište u Samoboru i Školu stranih jezika Narodnog sveučilišta grada Zagreba. ${ }^{41}$

U Galeriji "Centar" u Gundulićevoj 12 održavala se izložba slika slikarâ koji su sudjelovali na Internationalen Malerwochen u Štajerskoj. Organizator ovih likovnih tjedana bilo je Vijeće za kulturu štajerske Pokrajinske vlade, a voditelj direktor "Neue Galerie“ iz Graza. Slikari iz triju zemalja - Austrije, Italije i Jugoslavije - po četiri su tjedna boravili i slikali u renesansnom dvorcu Retzhofu, a zatim su izlagali svoje radove u "Neue Galerie“ u Grazu. Sudionici 2. međunarodnih slikarskih tjedana 1967. bili su R. Kriesche, H. Painitz i D. Prelog (Austrija), G. Novelli, G. Strazza i C. Zotti (Italija) te M. Galić, A. Jemec i R. Reljić (Jugoslavija). Zagrebačka izložba organizirana je u povodu „Štajerskog tjedna“, a na otvaranju govorio je potpredsjednik štajerske Pokrajinske vlade dr. F. Koren..$^{42} \cup$ Centru, pak, za estetski odgoj mladih u Mošćeničkoj 1 bila je otvorena izložba ulja, pastela i grafika, a izlagači su bili slikari iz Graza: Horvat, Lojen i Messner. ${ }^{43}$

Pred kraj „Štajerskog tjedna“ u kinu "Jadran“ održana je projekcija filmova u boji o Štajerskoj i Grazu, pod zajedničkim nazivom „,Štajerska u riječi i slici“. ${ }^{44}$ Upravo u povodu „Štajerskog tjedna“ na informativnim šalterima zagrebačkih putničkih i turističkih poslovnica našao se bogato i ukusno opremljen „Vodič kroz Graz" autora Vladimira Kekića iz Zagreba, koji je bio i vlastiti izdavač. Prospekt, zapravo brošurica na 35 stranica, pružala je domaćim turistima obilje zanimljivih podataka o glavnom gradu Štajerske, plan grada, najznačajnije povijesne podatke, adrese važnijih galerija $i$ kulturnih institucija, upute $o$ trgovinama, servisima, prometnim vezama, ugostiteljskim lokalima i o svemu onome što

\footnotetext{
40 "Austrijski muzičari u Zagrebu“, Večernji list (Zagreb), 27. 4. 1968, 10.

${ }^{41}$ "Ugledni austrijski andragozi u Zagrebu“, Večernji list (Zagreb), 24. 4. 1968, 9.

42 "Izložba iz Graza u Galeriji 'Centar'“, Isto, 9.

43 Večernji list (Zagreb), 22. 4. 1968, 5.

44 "Muzika i riječ", Večernji list (Zagreb), 26. 4. 1968, 8.
} 
je zagrebačkog i hrvatskog posjetitelja moglo zanimati prilikom prvoga posjeta Grazu. Zamjenik gradonačelnika Graza, dipl. inž. Alexander Götz, izrazio je u prospektu dobrodošlicu našim turistima u Grazu, a o kvalitetama tog vodiča najpovoljnije su se izrazili i funkcionari iz Graza koji su tijekom „Štajerskih dana“ boravili u Zagrebu. ${ }^{45}$

\section{Zaključak}

Novinski izvještaji sa svih održanih priredbi redom su pohvalni i afirmativni. Naglašava se „srdačnost Zagrepčana prema Gračanima na svakom koraku.“ Tome su svakako pridonosile ljupke i simpatične hostese iz Graza, koje su s karakterističnim štajerskim zelenim šeširićima dijelile na brojnim istaknutijim turističkim punktovima u gradu prospekte Graza i Štajerske. O popularnosti „Štajerskog tjedna“ u gradu dovoljno govori i velik interes Zagrepčana za prigodnu izložbu „Zelena Štajerska i cvjetni Graz“ u Umjetničkom paviljonu, kao i dobar posjet na svim održanim predavanjima i projekcijama istaknutih predstavnika javnog i kulturnog života Štajerske. Sveukupno gledajući, „„Štajerski tjedan“ u Zagrebu uspio je iznad svih očekivanja. Stoga su i štajerski gosti neposredno nakon završetka manifestacije izjavili kako „na atmosferu na koju su naišli u gradu gosti iz Štajerske žele uzvratiti 'istom mjerom' i u Grazu. "Na Zagrebu, tj. na gradskim vlastima bila je zadaća definiranja datuma svog posjeta i razrada fizionomije vlastitog "tjedna“. Zadatak - što je naglasio Ratko Karlović - "neće biti nimalo lak“ jer su gosti iz Austrije „,vrlo uspješno predstavili turističke, privredne i kulturne karakteristike svoje pokrajine Štajerske i njenog centra Graza. ${ }^{\text {“46 }}$

U okviru od tada započete suradnje, Turistički savez Graza i Štajerske organizirao je u narednom razdoblju u Zagrebu četiri konferencije za tisak, dok su zagrebački novinari bili na studijskom putovanju u Grazu i Štajerskoj u dvama navratima. Godine 1969. izvršeno je studijsko putovanje na ovim područjima od strane turističkih radnika Zagreba i zagrebačkog područja, među kojima su bili i predstavnici komuna, ugostitelja i arhitekata, s ciljem upoznavanja turističko-razvojne politike ovog dijela Austrije, s posebnim naglaskom na manja mjesta i kupališne kapacitete. ${ }^{47}$

Turistički savez Zagreba organizirao je u Grazu u navedenom razdoblju tri konferencije za tisak, a tijekom lipnja 1970. održana je i četvrta. Osim toga, Turistički savez Zagreba je u četirima navratima uz pomoć djevojaka iz Hrvatske odjevenih u narodnim nošnjama distribuirao na najfrekventnijim ulicama i trgovima Graza turističko-propagandne materijale o Zagrebu i središnjoj Hrvatskoj. ${ }^{48}$ Gradački novinari boravili su često u Zagrebu i o tome u svojim listovima objavili tekstove o Zagrebu, posebno u vezi s manifestacijama koje su se redovito organizirale u glavnome hrvatskom gradu. Zagrebački je Turistički savez organizirao i studijski boravak predstavnikâ organizatorâ putovanja iz Graza u Zagrebu i na području Hrvatskog zagorja. Uz podršku TS-a Graza i TS-a Zagreba, organizirao je u Grazu besplatno prikazivanje filma u boji o „Smotri folklora“ u Zagrebu u trajanju od deset dana. ${ }^{49}$

45 "Sve o Grazu“, Večernji list (Zagreb), 25. 4. 1968, 8.

46 „Pivu odgovor - vinom!“, Večernji list (Zagreb), 25. 4. 1968, 8.

47 Hrvatski državni arhiv (dalje: HDA), Savjet za odnose s inozemstvom Izvršnog vijeća Sabora Socijalističke Republike Hrvatske, HR-HDA 1409, Austrija 1970/71, Republički sekretarijat za privredu Zagreb, elaborat „Ekonomski odnosi Jugoslavija-Austrija“, 6.

48 Isto.

49 Isto. 
Na tradicionalnoj „Štajerskoj jeseni“ svoje su vidljivo i značajno mjesto imali i zagrebački predstavnici. Njihovim gostovanjem najavljeno je skoro sudjelovanje hrvatskih gostiju na tzv. "Zagrebačkom tjednu“ u Grazu i Štajerskoj. Tako je u okviru „Štajerskih jeseni“ austrijski radio u Grazu od 23. rujna do 2. listopada organizirao niz koncertnih priredaba pod zajedničkim nazivom „Muzički protokol 1968.“, na kojima su se austrijskoj publici i radijskim slušateljima predstavili, pored anasambala iz Austrije, i ansambli iz pet susjednih zemalja, prikazavši suvremeno stvaralaštvo na polju muzike sa svoga područja. Od jugoslavenskih ansambala na priredbi su sudjelovali Simfonijski orkestar Radio-televizije Ljubljana pod ravnanjem Sama Hubada i Komorni orkestar Radio-televizije Zagreb (RTZ) pod dirigentskom palicom Krešimira Šipuša. ${ }^{50}$ Komorni orkestar RTZ na svome programu izveo je isključivo praizvedbe djela koja su, prema narudžbi RTZ-a, napisali mladi, ali tada već afirmirani zagrebački kompozitori: Dubravko Detoni, Stanko Horvat, Igor Kuljerić, Ruben Radica i Krešimir Šipuš. Kako svjedoče kritike u austrijskim medijima, koncert je doživio velik uspjeh među publikom i kritikom..$^{51}$

Na temelju ovakvih oblika suradnje proizašla su organizirana grupna i masovnija individualna putovanja u obama smjerovima. Od strane grada Graza, Zagreb je uvršten u njihove kružne ture kroz Hrvatsku, zatim kao isključivi cilj jednodnevnog posjeta, prvenstveno radi trgovačkih motiva, te vikend posjeta Zagrebu, ali i u turističko-autobusne veze Graz - Krapinske toplice. U pripremi bile su i sljedeće akcije:

1. zajednički plasman kongresne ponude Zagreb - Graz - Opatija, na zajedničku inicijativu turističkih saveza ovih gradova

2. međusobni studijsko-informativni posjeti turističkih vodiča - iz Graza na područje Zagreba i središnje Hrvatske

3. u zajednici s Klagenfurtom, Villachom, Salzburgom i Münchenom plasman ovih poteza u velikim putovanjima za Jadran na tržištima zapadne Njemačke, Beneluxa, Velike Britanije, Danske, sjeverne Francuske i sjeverne Švicarske, da bi se smanjila konkurencija poteza München - Brenner - Trst

4. organiziranje "Zagrebačkih tjedana“ (orijentacija na proljeće 1971.) u Grazu, koji se nisu ranije organizirali zbog izrazito loše cestovne veze Zagreb - Graz. ${ }^{52}$

50 Krešimir Šipuš je od 1968. bio stalni dirigent i umjetnički rukovoditelj muzičkih ansambala RTZ-a.

51 Pod naslovom „Nova muzika - novi aspekti“ kritičar Karl Haidmayer u Kleine Zeitungu piše: „Četvrti koncert muzičkog protokola izveo je Komorni orkestar Radio-televizije Zagreb pod izvrsnim vodstvom Krešimira Šipuša, a k tome je imao na raspolaganju odlične soliste: Ranka Filjaka, Vladimira Ruždjaka i Janku Šanjek (na Martenot - valovima, što je za Graz također novi, elektronski instrument)." U novinama Südost-Tagespost Rudolf Liszt svoj članak završava riječima: „... orkestar je svirao blistavo. Divnom disciplinom, kao što se i Krešimir Šipuš pokazao dirigentom od formata..." Herbert Schneiber u bečkom Kurieru je, pak, napisao: „Pjevač Vladimir Ruždjak, koji pripada međunarodnoj eliti pjevača, svoj je čuvstveni i plemeniti bariton izložio s mnogo stila, osjećaja i ukusa..." Isti kritičar opširno je ocijenio djelo Dubravka Detonija: „On iskušava materijal orkestra, organizaciju tonova i strukturu provodi s fantazijom i senzibilnošću, umije u crescendu gudača, što pršte nad orgel-punktom duvača, uliti prijetnju, pomake i protupomake sitnih formi koje pretvara u igru punu estetske draži, poput lepeze razvija mekani ton na malom bubnju, lagano dotiče zvona u pravom trenutku, ne dosađuje novim konvencijama. Ukratko: kompozija je kratka i dobra.“, „Uspjeh zagrebačkih muzičara“, Večernji list (Zagreb), 11. 10. 1968, 7.

52 HDA, Savjet za odnose s inozemstvom Izvršnog vijeća Sabora Socijalističke Republike Hrvatske, HR-HDA 1409, Austrija 1970/71, Republički sekretarijat za privredu Zagreb, Ekonomski odnosi Jugoslavija-Austrija, 7. 
lako je opća ocjena suradnje bila izrazito pozitivna te su obje strane naglasile da je ona plodonosna, srdačna i iskrena, kao i to da ima dugoročnu perspektivu, jasno su artikulirani postojeći negativni faktori koji su sprečavali veće učinke međusobne suradnje ovih dvaju gradova te Štajerske i Hrvatske u cjelini. Prije svega, isticala se nedovršenost Zagorske magistrale, nepotpuna asfaltiranost poteza Sutla - Rogatec, defektnost asfaltnog poteza Zagreb - Varaždin - Maribor te nedovršenost asfaltnog poteza Mursko Središće - Lendava u pravcu Gornje Radgone. Također je naglašena nedovoljna opremljenost toplica u okolici Zagreba, s određenim izuzetkom Krapinskih toplica. Na planu razvoja tzv. omladinskog turizma isticala se nepostignuta suglasnost školskih vlasti Austrije da u programu đačkih ekskurzija uvrštavaju i posjet gradu Zagrebu. Također valja naglasiti kako se ni s hrvatske strane na ovom planu nisu poduzimale velike inicijative jer se čekalo prethodno uklanjanje negativnih fakotra u stanju cestovnih prometnica Zagreba i Graza. ${ }^{53}$

lako dogovoreni „Hrvatski tjedan“ u Grazu nije bio ostvaren iz materijalnih razloga, ne može se poreći kako su ovi kontakti, uspostavljeni 1967. godine, predstavljali ključnu točku u razvoju daljnjih odnosa Hrvatske i Štajerske. Pritom nije bila riječ samo o turističkoj ponudi obiju strana već i o suradnji na gospodarskom, kulturnom i obrazovnom području.

53 U tjedniku Vikend među ostalim se promovirala udobna vožnja željeznicom od Zagreba do Graza, i to ekspresnim vlakom za 58,80 dinara (ekspresni), II $(41,00)$. „Putujte udobno željeznicom“, Vikend (Zagreb), 2, 1968, 40. 